\title{
Participation of Digital Promotion in the Promotional Mix of Small Enterprises
}

\author{
Momčilo Poljić \\ University of East Sarajevo, Faculty of Economics Brčko, Brčko District of Bosnia and Herzegovina, Bosnia and Herzegovina \\ Dejan Tešić \\ University of East Sarajevo, Faculty of Economics Brčko, Brčko District of Bosnia and Herzegovina, Bosnia and Herzegovina \\ Neda Košutić \\ Komunalno Brčko Public Utility, Brčko District of Bosnia and Herzegovina, Bosnia and Herzegovina
}

\begin{abstract}
The digital revolution places the imperative of accepting the fact that all spheres of business must be modernized. As the core of all functions in the company changes, the marketing function changes. The marketing mix of companies is changing in terms of using digital technologies to implement marketing strategies. In addition to innovation in the domain of creating products, price construction and distribution channels, promotion is also being innovated. Communication of product offers to customers requires a modern approach that will be compatible with the turbulent time in which business is currently taking place. Consumers are turning more and more to modern technologies, and the increasingly popular digital media is the way to reach a modern consumer. In this sense, alongside traditional promotion, the company uses digital promotion as a way of its overall performance in promoting its offer. Among other things, the use of digital promotion channels depends on the size of the company.

The subject of paper is the usage of digital promotion in small enterprises in the Brčko District of Bosnia and Herzegovina. The aim of the paper is to examine participation and significance of digital promotion in the overall promotion of small enterprises of the Brčko District of Bosnia and Herzegovina and to determine the degree of usefulness and satisfaction based on the use of digital promotion by the mentioned enterprises.
\end{abstract}

\section{Keywords}

Digital promotion, promotional mix, technology, internet.

\section{Digital marketing - concept and significance}

One of the main changes in traditional marketing was determined by the emergence of digital marketing, which required reviewing the marketing strategies of companies that want to remain competitive in the new digital era (Baltes, 2015, p. 111). Almost daily, new technologies, new devices and new applications, developed precisely for these technologies and devices, are emerging on the market which should enable users to get faster and better digital communication. That has its advantages and disadvantages. The benefits are certainly in connecting people from different parts of the world and sharing experiences, obtaining faster the necessary information related to the products and services that customers are interested in, finding the desired products and services, online shopping, online payments, etc. The undeniable fact is that the progress of technology has greatly facilitated everyday life. Today, people do not have to leave their homes to do almost all activities, primarily buying, paying bills, completing business meetings, etc., if they own a computer and access to the Internet. Digitization also has its advantages from the point of view of companies, and they are primarily reflected in the reduction of the cost of arriving to the broad auditorium, especially if the costs of traditional marketing are compared (Jayaram, Manrai \& Manrai, 2015, p. 123). On the other hand, people have adapted themselves too quickly to new technological and/or digital trends, and in this way created a 
certain virtual world in which people often stay, sometimes more, than in the real world. Today, it is almost impossible to imagine a day without the use of the Internet, social networks, mobile applications and similar digital technologies. According to the American Pew Research Center, 89\% of US citizens are actively using the Internet, and nine out of ten citizens use the Internet daily (Pew Research Center, 2018). This trend is not unique only to American society. Global marketing company We are social in Singapore is publishing a comprehensive report on the scope of digital technology, so the following information was released in 2018 (We are social):

- 4.021 billion people, or $53 \%$ of the world's population, use the Internet daily,

- Mobile devices are actively used 5.135 billion people, or $68 \%$ of the world's population,

- 3.196 billion people, or $42 \%$ of the population, have profiles on social networks.

- Nearly three billion social network users (2.958 billion people) access their profiles using mobile phone, which is $39 \%$ of the world's population.

It is interesting to note that the same agency released the same data two years ago, but then they had less value (Tesic, 2017, page 313), that is:

- 3.42 billion people use the Internet on a daily basis,

- Mobile devices are actively used by 3.79 billion people,

- Profile on social networks has over 2.3 billion users,

- Nearly two billion social network users access their profiles through their mobile phone.

Previously stated data indicates that in just two years there has been an increase in the number of people using the Internet and mobile devices every day, and also that the number of social network users and users who access their social network profiles through mobile devices has increased. These data are significant for all companies that plan their marketing activities, because they significantly change the current, traditional, way of communication with customers.

Observing these data, we can see why traditional marketing has evolved into the digital world. Marketing must follow the customer, and since the data show that customers slowly become dependent on digital technologies, marketing has found a way to continue communicating with customers, using only a new platform and using digital communications channels. An American study has shown that average people use at least four different media such as online news portals, Word of Mouth, TV, Facebook, Twitter, YouTube, LinkedIn, to get information (Lewis, 2008). Business communication today is the subject of a revolution thanks to social networks such as Facebook and Twitter, which are commonly used as credible business tools (Levy, Birkner, 2011). Communication channels are much more. What is different in the current digital environment is "speed, interconnectivity, and hence the complexity of these elements" (Kung, 2008, p. 83). Therefore, it is very important to define the term "digital marketing" well. The Digital Marketing Institute defines this term as "the use of digital technologies to create integrated, targeted and measurable communications that can help capture and retain customers while building deeper relationships with them" (Smith, 2007 in Wymbs, 2011, p. 94).

\section{Guiding the company to digital marketing}

As we have already pointed out, businesses must follow customers, especially when it comes to marketing activities. Customers have already adapted to the digital era and the lifestyle in which digitization prevails, so businesses need to "digitize" their marketing efforts. Given the use of the Internet by consumers, it is logical that marketing of modern companies uses online media as an access point with customers related to product promotion and proliferation (Jackson \& Ahuja, 2016). Digitization has also changed the relationship between businesses and customers, that is, power is now in the hands of customers. Sharing information on the Internet has given everyone the opportunity to express their opinions, which has led people to trust other people more than organizations (Greenberg, 2010a, Greenberg, 2010b). Such a change in customer mindset has led companies to the situation that they have to change their way of communicating with customers. Companies now recognize the need to listen to their customers, engage them in conversation, make them more transparent, and communicate with customers more openly and sensibly (Karjaluoto, Mustonen \& Ulkuniemi, 2015). What does this mean for businesses in practice? First of all, marketing communications now include creating 
online communities, generating potential partners from online environments and collaborating with customers to better understand their needs (Weber, 2009). Businesses now need to create topics and the flow of communication, actively participate in communication and exchange of opinions in order to prevent the creation of negative attitudes towards customers in relation to the company and its assortment. Many digital communication tools can help them with this, among which the most commonly used are e-mail, social networks, smartphones and applications developed for them, blogs and web portals. These are not the only tools of digital marketing but are the most often used. It should be noted here that digitalization tools, which are the result of exceptional global technological advancement, are developing almost daily and are constantly improving. Let us just take for example the social network Facebook, which appeared in 2004 and today has more than 2 billion users around the world and has a tendency of steady growth. Each of these marketing tools can be a whole for itself, so today we have marketing of social networks, web marketing, social marketing, and so on.

Companies need to keep in mind that technology in the 21 st century is rapidly evolving and changing and that it is necessary to keep up-todate with events in this field in order to keep up with customers who constantly accept these technologies and import them into all spheres of their lives.

\section{Preparation of data, sample and data processing}

Digital promotion is increasing in small and medium enterprises of Bosnia and Herzegovina. For the purpose of research in this paper, we focused on the small enterprises of the Brčko District of Bosnia and Herzegovina. For the classification of enterprises in small, medium and large, we have chosen the size criterion that small businesses are those that have up to fifty (50) employees, medium businesses have the average of fifty (50) to two hundred and fifty (250), and large over two hundred and fifty workers (250). Small enterprises were selected because of their presence on the territory of the Brčko District $\mathrm{B} \& \mathrm{H}$ and according to the data of the Chamber of Commerce of the Brčko District of B\&H, these companies account for $90 \%$ of all companies that exist in the territory of the district. Also, the benefits of digital promotion, as well as the low budget required for the realization of digital promotion, are imposed as a logical move in the desire of small businesses to improve their business. About 1000 small and medium enterprises are registered in the Brčko District of $\mathrm{B} \& \mathrm{H}$, the majority of which are small enterprises of up to 50 employees. According to some methodologies of enterprise classification in this category, micro-enterprises with the number of employees from one (1) employee to ten (10) employees are included. As part of our work, micro enterprises are classified into small enterprises.

The data were collected on the basis of a questionnaire sent to two hundred (200) randomly selected addresses of small businesses in the Brčko District. Questionnaires were delivered personally and using e-mail. The research was planned for a period of two months from December 2017 and January 2018. During this time period we received 36 responses, i.e. filled in questionnaires. Companies from different activities were surveyed and there were no restrictions in that regard. All received questionnaires are complete and there is no missing data. We consider a response of $18 \%$ as a good response, and a sample of 36 units sufficient for valid statistical data processing.

Data processing was performed in the SPSS statistical package, and descriptive and inferential statistics were used for the analysis. Descriptive statistics were used in the part of representing frequencies, mean and standard deviation of data, and the inferential statistics were used in the correlation checking section between the variables that were processed in the questionnaire. As the theme of the paper itself is the relation between the use of traditional and modern promotion tools in small enterprises, the research was conducted in the direction of discovering the mentioned relationship. For the purpose of research, a questionnaire was created consisting of ten (10) questions. Questions in the questionnaire were designed so that the respondents had to give answers on the number of employees, their satisfaction with market share, their satisfaction with the competitiveness, the frequency of the use of overall promotion of the company, the frequency of using traditional and modern promotion, the frequency of using traditional and modern promotion tools and ultimately satisfaction with the infrastructure for conducting traditional and modern promotion. Possible answers to questions about satisfaction with market share, competitiveness and traditional and modern promotion, and the frequency of the use of traditional and modern promotion tools 
were formed in such a way that they were given on the five-point Likert scale. The offered answers to questions about satisfaction with market share, competitiveness and traditional and modern promotion are given on the scale in the following form: 1-absolutely dissatisfied, 2-moderately dissatisfied, 3-neutral, 4-moderately satisfied and 5absolutely satisfied. The offered answers to the questions about the frequency of the use of traditional and modern promotion tools are given on a scale in the following form: 1-never, 2-rarely, 3sometimes, 4-often and 5-always. The answer to the question about the number of employees is given on a ratio scale.

\section{Research results}

Based on the data processing in this paper, the results are presented below. As regards the data on the number of employees, they are presented in Table 1. Based on the sample of 36 enterprises, the average number of workers is 15.36 , the median is 14 workers, the modus is 12 workers, the smallest number of workers is 1 , and the largest number of workers is 46 . The standard deviation is 9.16 workers.

Table 1 Number of employees in surveyed enterprises

\begin{tabular}{l|c}
\hline \multicolumn{1}{c|}{ Employee data } & Value \\
\hline Mean & 15.36 \\
\hline Median & 14.00 \\
\hline Modus & 12 \\
\hline Standard deviation & 9.159 \\
\hline Minimum & 1 \\
\hline Maximum & 46 \\
\hline \multicolumn{2}{c}{ Source: The authors }
\end{tabular}

Table 2 shows data about market share and competitiveness satisfaction. The average value of the variable market share satisfaction is 3.64 with the standard deviation of 0.683 and based on the ttest we can conclude that the attitude of the enterprise towards market participation is not neutral $(\mathrm{p}$ $=0.000<0.05)$ but is moderately satisfied. For attitude neutrality, satisfaction hypotheses are set: $\mathrm{H} 0$ : mean $=3, \mathrm{H} 1$ : mean $\neq 3$.

The mean of the variable satisfaction with competitiveness is 3.58 with the standard deviation 0.692 and here we conclude that the attitude of the enterprise is also not neutral $(p=0.000$ $<0.05$ ), but there is also moderate satisfaction.
Table 2 Satisfaction with Market Participation and Competitiveness

\begin{tabular}{l|c|c|c|c|c}
\hline & $\mathbf{N}$ & Min & Max & Mean & $\begin{array}{c}\text { Standard } \\
\text { deviation }\end{array}$ \\
\hline $\begin{array}{l}\text { Market } \\
\text { share } \\
\text { satisfaction }\end{array}$ & 36 & 2 & 5 & 3.64 & 0.683 \\
\hline $\begin{array}{l}\text { Satisfaction } \\
\text { with compe- } \\
\text { titiveness }\end{array}$ & 36 & 2 & 5 & 3.58 & 0.692 \\
\hline
\end{tabular}

Source: The authors

When we talk about satisfaction with the traditional, modern and overall promotion of the companies surveyed, we come up with the results shown in Table 3 . The mean of the variable frequency of using overall promotion is 3.53 with a standard deviation of 0.774 . The mean of the variable frequency of using traditional promotional tools is 3.28 with a standard deviation of 0.815 .

Table 3 Frequency of use of promotion

\begin{tabular}{l|c|c|c|c|c}
\hline & $\mathbf{N}$ & Min & Max & Mean & $\begin{array}{c}\text { Standard } \\
\text { deviation }\end{array}$ \\
\hline $\begin{array}{l}\text { Frequency of } \\
\text { using overall } \\
\text { promotion }\end{array}$ & 36 & 2 & 5 & 3.53 & 0.774 \\
\hline $\begin{array}{l}\text { Frequency of } \\
\text { using }\end{array}$ & 36 & 1 & 5 & 3.28 & 0.815 \\
$\begin{array}{l}\text { traditional } \\
\text { promotion } \\
\text { tools }\end{array}$ & 36 & 1 & 4 & 3.25 & 0.732 \\
\hline $\begin{array}{l}\text { Frequency of } \\
\text { using modern } \\
\text { promotional } \\
\text { tools }\end{array}$ & 36 & & & & \\
\hline
\end{tabular}

Source: The authors

The mean of the variable frequency of using modern promotional tools is 3.25 with a standard deviation of 0.732 . Based on the t-test, we conclude that the attitude of the all three companies in the sample model are not neutral $(\mathrm{p}=0,000$; 0,$048 ; 0,048<0.05$ respectively), but that the surveyed companies often use total, traditional and modern promotion $(\mathrm{p}=0.000 ; 0.024 ; 0.024<0.05$ respectively).

Table 4 presents the results of the frequency of the use of traditional promotional tools by the companies included in the sample. The answers to the questions about frequency are given on the Likert scale ( 1 - never, 2 - rarely, 3 - sometimes, 4 - often, 5 - always). The surveyed companies replied that the mean of the frequency of using television as a traditional medium is 2.97 with a standard deviation of 1.540 and based on the t-test (p $=0.914>0.05$ ), we conclude that surveyed com- 
panies sometimes use television for their promotional activities. Sometimes the radio is used as a tool of traditional promotion with a mean of 2.89 and standard deviation of $1.430(\mathrm{p}=0.644>0.05)$.

Regarding the use of daily press releases with a mean of 2.17 and a standard value of 1.363 , a magazine with a mean of 1.56 and a standard value of 0.843 , a public relations with a mean of 2.22 and a standard deviation of 1.149 and a billboard with a mean of 2.36 and standard deviation 1.334 as traditional promotional tools, they are rarely used by surveyed companies $(p=0.000 ; 0.000$; $0.000 ; 0.004<0.05$ respectively). Surveyed companies sometimes also use personal sales with a mean of 3.39 with a standard deviation of 1.315 and sponsoring activities with a mean value of 2.69 and a standard deviation of $1.238(\mathrm{p}=0.085$; $0.148>0.05$ respectively), and more often promotion at the point of sale with a mean of 3.78 and a standard deviation of $1.245(\mathrm{p}=0.000<0.05)$.

Table 5 contains data on the frequency of the use of modern tools for the promotion of surveyed companies. From modern promotional tools that are used rarely there are advertisements on the search engine with a mean of 2.31 and a standard deviation of 1.283 , links with a mean of 1.69 and a standard deviation of 1.009 , reviews with a mean of 1.69 and a standard deviation of 0.920 , forums with a mean of 1.72 and a standard deviation of 0.849 , a blog with a mean of 1.42 and a standard deviation of 0.604 and a mobile application with a mean of 1.61 and a standard deviation of 0.964 , and the conclusion was made on the basis of the t-test $(\mathrm{p}=0.002 ; 0.000 ; 0.000 ; 0.000$; $0.000<0.05$ respectively).

Table 4 Frequency of using traditional promotion tools

\begin{tabular}{l|c|c|c|c|c}
\hline & $\mathrm{N}$ & Min & Max & Mean & $\begin{array}{c}\text { Standard } \\
\text { deviation }\end{array}$ \\
\hline $\begin{array}{l}\text { Use of } \\
\text { television for } \\
\text { promotion }\end{array}$ & 36 & 1 & 5 & 2.97 & 1.540 \\
\hline $\begin{array}{l}\text { Use of radio } \\
\text { for } \\
\text { promotion }\end{array}$ & 36 & 1 & 5 & 2.89 & 1.430 \\
$\begin{array}{l}\text { Use of daily } \\
\text { press for } \\
\text { promotion }\end{array}$ & 36 & 1 & 5 & 2.17 & 1.363 \\
\hline $\begin{array}{l}\text { Use of mag- } \\
\text { azines in } \\
\text { promotion }\end{array}$ & 36 & 1 & 4 & 1.56 & 0.843 \\
\hline $\begin{array}{l}\text { Use of } \\
\text { billboard in } \\
\text { promotion }\end{array}$ & 36 & 1 & 5 & 2.36 & 1.334 \\
\hline
\end{tabular}

\begin{tabular}{l|c|c|c|c|c}
\hline $\begin{array}{l}\text { Promotion at } \\
\text { the point of } \\
\text { sale }\end{array}$ & 36 & 1 & 5 & 3.78 & 1.245 \\
\hline $\begin{array}{l}\text { Public } \\
\text { relations }\end{array}$ & 36 & 1 & 5 & 2.22 & 1.149 \\
\hline $\begin{array}{l}\text { Personal } \\
\text { sales }\end{array}$ & 36 & 1 & 5 & 3.39 & 1.315 \\
\hline $\begin{array}{l}\text { Sponsor- } \\
\text { ships }\end{array}$ & 36 & 1 & 5 & 2.69 & 1.238 \\
\hline
\end{tabular}

Source: The authors

SMS messages with a mean value of 3.00 and a standard deviation of 1.265 are used sometimes $(p=1,000>0.05)$. Modern tools used more often by the surveyed companies are an e-mail with a mean of 3.53 and a standard deviation of 1.464 (p $=0.019<0.05)$ and a social network with a mean of 3.58 and a standard deviation of $1.442(\mathrm{p}=$ $0.010<0.05$ ).

Table 5 Frequency of using modern promotional tools

\begin{tabular}{l|c|c|c|c|c}
\hline & $\mathbf{N}$ & Min & Max & Mean & $\begin{array}{c}\text { Standard } \\
\text { deviation }\end{array}$ \\
\hline E-mail & 36 & 1 & 5 & 3.53 & 1.464 \\
\hline SMS & 36 & 1 & 5 & 3.00 & 1.265 \\
\hline $\begin{array}{l}\text { Advertise- } \\
\begin{array}{l}\text { ments on } \\
\text { the search } \\
\text { engine }\end{array}\end{array}$ & 36 & 1 & 5 & 2.31 & 1.283 \\
\hline Links & 36 & 1 & 5 & 1.69 & 1.009 \\
\hline Reviews & 36 & 1 & 4 & 1.69 & 0.920 \\
\hline $\begin{array}{l}\text { The social } \\
\text { network }\end{array}$ & 36 & 1 & 5 & 3.58 & 1.442 \\
\hline Forums & 36 & 1 & 4 & 1.72 & 0.849 \\
\hline Blog & 36 & 1 & 3 & 1.42 & 0.604 \\
\hline $\begin{array}{l}\text { Mobile } \\
\text { applica- } \\
\text { tions }\end{array}$ & 36 & 1 & 5 & 1.61 & 0,964 \\
\hline
\end{tabular}

Source: The authors

Table 6 shows satisfaction with the infrastructure for the implementation of traditional and modern promotion tools. Variable satisfaction with infrastructure for traditional promotion has a mean of 3.58 with a standard deviation of 0.841 . Variable satisfaction with infrastructure for modern promotion has a mean of 3.78 with a standard deviation of 1.017. On the basis of the answers we can see that the surveyed companies are mostly satisfied with the infrastructure for implementing traditional promotion tools $(\mathrm{p}=0.000<0.05)$ and with the infrastructure for implementing modern promotional tools $(\mathrm{p}=0.000<0.05)$. 
Table 6 Satisfaction with the infrastructure for the implementation of traditional and modern promotion tools

\begin{tabular}{l|c|c|c|c|c}
\hline & $\mathbf{N}$ & Min & Max & Mean & $\begin{array}{l}\text { Standard } \\
\text { deviation }\end{array}$ \\
\hline $\begin{array}{l}\text { Satisfaction } \\
\text { with the } \\
\text { infrastruc- } \\
\text { ture for } \\
\text { traditional } \\
\text { promotion }\end{array}$ & 36 & 2 & 5 & 3.58 & 0.841 \\
\hline $\begin{array}{l}\text { Satisfaction } \\
\text { with the } \\
\text { infrastruc- } \\
\text { ture for } \\
\text { modern } \\
\text { promotion }\end{array}$ & 36 & 2 & 5 & 3.78 & 1.017 \\
\hline
\end{tabular}

Source: The authors

When we look at the correlation (Table 7) between satisfaction with market share, satisfaction with competitiveness, frequency of use of overall promotion, frequency of using traditional promotional tools and the frequency of using modern promotional tools, we can conclude that there is a significant medium strength correlation between the satisfaction with competitiveness and the frequency of using traditional promotion tools $\mathrm{r}=$ $0.414 ; \mathrm{p}=0.012$ ) and satisfaction with market share with the frequency of using traditional promotional tools $(r=0.443 ; p=0.007)$.

There is a strong significant correlation between satisfaction with market share and satisfaction with competitiveness $(r=0,761 ; p=0,000)$, which is logical if we consider competitiveness as the ability to retain and increase market share.

Table 7 Correlation between satisfaction with market share and competitiveness with overall promotion, traditional and modern promotion

\begin{tabular}{|c|c|c|c|c|c|c|}
\hline & & 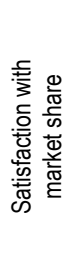 & 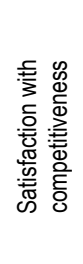 & 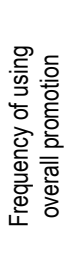 & 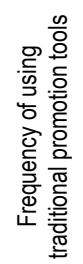 & 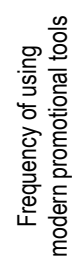 \\
\hline \multirow{3}{*}{ 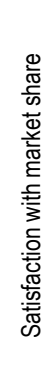 } & 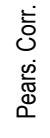 & 1 & $0.761^{* *}$ & 0.047 & $0.443^{* *}$ & -0.100 \\
\hline & 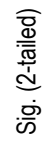 & & 0.000 & 0.787 & 0.007 & 0.561 \\
\hline & $z$ & 36 & 36 & 36 & 36 & 36 \\
\hline
\end{tabular}

\begin{tabular}{|c|c|c|c|c|c|c|}
\hline \multirow{3}{*}{ 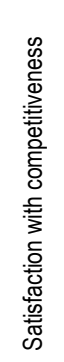 } & 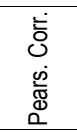 & $0.761^{* *}$ & 1 & 0.049 & $0.414^{*}$ & -0.127 \\
\hline & 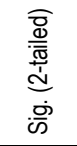 & 0.000 & & 0.777 & 0.012 & 0.461 \\
\hline & $z$ & 36 & 36 & 36 & 36 & 36 \\
\hline \multirow{3}{*}{ 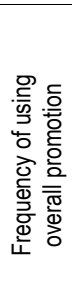 } & 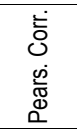 & 0.047 & 0.049 & 1 & 0.214 & 0.113 \\
\hline & 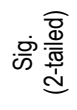 & 0.787 & 0.777 & & 0.210 & 0.510 \\
\hline & $z$ & 36 & 36 & 36 & 36 & 36 \\
\hline \multirow{3}{*}{ 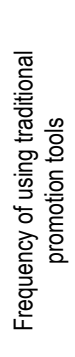 } & 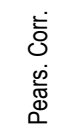 & $0.443^{* *}$ & $0.414^{*}$ & 0.214 & 1 & 0.072 \\
\hline & 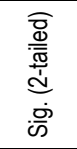 & 0.007 & 0.012 & 0.210 & & 0.677 \\
\hline & $z$ & 36 & 36 & 36 & 36 & 36 \\
\hline \multirow{3}{*}{ 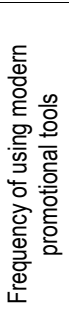 } & 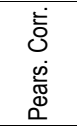 & -0.100 & -0.127 & 0.113 & 0.072 & 1 \\
\hline & 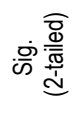 & 0.561 & 0.461 & 0.510 & 0.677 & \\
\hline & $z$ & 36 & 36 & 36 & 36 & 36 \\
\hline \multicolumn{7}{|c|}{ **. Correlation is significant at alpha $=0.01$} \\
\hline & antion is & in & קר & & & \\
\hline
\end{tabular}

Source: The authors

It is interesting to note that there is no significant correlation between the frequency of the use of traditional promotional tools, the frequency of using modern promotional tools, satisfaction with the infrastructure for applying traditional promotion, and infrastructure satisfaction for applying modern promotion (Table 8). 
Table 8 Correlation between satisfaction with traditional and modern promotion tools with satisfaction with the infrastructure for application of traditional and modern promotion.

\begin{tabular}{|c|c|c|c|c|c|}
\hline & & 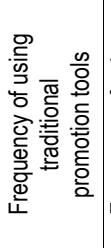 & 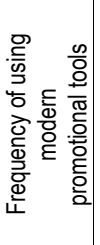 & 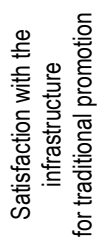 & 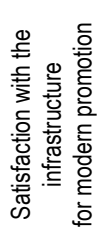 \\
\hline \multirow{3}{*}{ 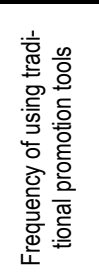 } & $\begin{array}{c}\text { Pearson } \\
\text { Correla- } \\
\text { tion }\end{array}$ & 1 & 0.072 & 0.132 & -0.096 \\
\hline & $\begin{array}{c}\text { Sig. } \\
\text { (2-tailed) }\end{array}$ & & 0.677 & 0.443 & 0.578 \\
\hline & $N$ & 36 & 36 & 36 & 36 \\
\hline \multirow{3}{*}{ 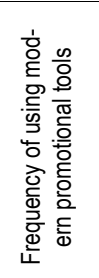 } & $\begin{array}{c}\text { Pearson } \\
\text { Correla- } \\
\text { tion }\end{array}$ & 0,072 & 1 & -0.058 & -0.038 \\
\hline & $\begin{array}{c}\text { Sig. } \\
\text { (2-tailed) }\end{array}$ & 0.677 & & 0.737 & 0.824 \\
\hline & $N$ & 36 & 36 & 36 & 36 \\
\hline \multirow{3}{*}{ 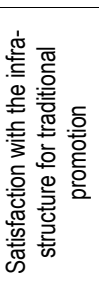 } & $\begin{array}{c}\text { Pearson } \\
\text { Correla- } \\
\text { tion }\end{array}$ & 0.132 & $\overline{0} \cdot \overline{0} 8$ & 1 & 0.189 \\
\hline & $\begin{array}{c}\text { Sig. } \\
\text { (2-tailed) }\end{array}$ & 0.443 & 0.737 & & 0.269 \\
\hline & $N$ & 36 & 36 & 36 & 36 \\
\hline \multirow{3}{*}{ 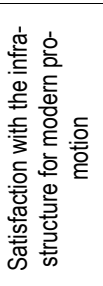 } & $\begin{array}{c}\text { Pearson } \\
\text { Correla- } \\
\text { tion }\end{array}$ & -0.096 & $\overline{0 .}$ & 0.189 & 1 \\
\hline & $\begin{array}{c}\text { Sig. } \\
\text { (2-tailed) }\end{array}$ & 0,578 & 0,824 & 0,269 & \\
\hline & $N$ & 36 & 36 & 36 & 36 \\
\hline
\end{tabular}

Source: The authors

\section{Limitations and recommendations for future research}

In this paper, there are several limitations related to research. First, only small enterprises are included in the work, although usually small and medium enterprises are taken as a group. Micro enterprises are also included in small enterprises. These two facts may possibly disable the comparison of this research with other similar surveys, which are usually done in small and mediumsized enterprises. The size of the sample is the second limitation of this paper, although the re- sponse to the survey is relatively good compared to similar research. A sample size of 36 companies is sufficient for statistical processing, but a larger sample would give more reliable conclusions regarding correlations between variables. Thirdly, enterprises of different activities are surveyed, which can also cause logically different answers, especially in the light of the answers to the questions in the use of modern promotional tools. In addition, the questions in the questionnaire were created in such a way that potential responses were given on the Likert scale and there was no opportunity to provide answers in the form of multiple responses and other forms of closed and open questions.

One of the recommendations for future research would be to do similar research with a focus on small and medium-sized enterprises. After that, the recommendation would be to do similar research in the countries of the region, and make their comparison. In addition to this, research in certain economic activities should be done. It would also be interesting to explore the financial aspect of investing in traditional and modern promotion both in Bosnia and Herzegovina and in the countries of the region.

\section{Conclusion}

Digitization is a phenomenon of the 21st century, which moves borders in the business world. Regardless of their type of activity and their size, companies must keep up with the times and accept the consequences of digitization. In addition to numerous advantages, digitization has some disadvantages. The number of Internet users is growing rapidly year after year, and imperative to the company is to approach modern consumers. One of the activities of a company that is greatly affected by the consequences of digitization is promotion.

Promotional activities in a contemporary, modern environment require shifting focus from traditional to modern promotional tools. As traditional promotional tools most commonly reported are television, radio, daily newspapers, magazines, billboards, sales promotion, personal sales, public relations and sponsorship. The most common forms of modern promotion, i.e. the most commonly used tools, are e-mail, text messages, search ads, links, reviews, social networks, forums, blogs and mobile applications.

The research in this paper has shown that small businesses use both traditional and modern promotion tools, although the frequency of using 
traditional tools prevails. Statistically significant medium strong correlation was confirmed between satisfaction with market share and competitiveness with the frequency of using traditional promotional tools. A statistically significant very strong correlation was confirmed between the company's satisfaction with competitiveness and the frequency of the use of traditional promotional tools. During the research, no statistically significant correlation was found between satisfaction with market share and satisfaction with competitiveness with the frequency of using modern promotional tools. This result leads us to conclusion that companies in the Brčko District of Bosnia and Herzegovina still rely more on traditional promotion tools.

Looking at individual tools of traditional and modern promotion, we can conclude that the most popular ones are the promotion at the point of sale and personal sales, and from modern tools, the most often used are e-mail and social networks. From traditional tools, magazines, daily newspapers and public relations are the least commonly used, and forums, blogs and mobile applications are the least commonly used by modern tools.sm

\section{References}

Baltes, L. P. (2015). Content marketing - the fundamental tool of digital marketing. Economic Sciences, 8(57), 111-118.

Greenberg, P. (2010a). CRM at the Speed of Light: Social CRM Strategies, Tools, and Techniques for Engaging Your Customers. New York: Mcgraw-Hill.

Greenberg, P. (2010b). The impact of CRM 2.0 on customer insight. Journal of Business \& Industrial Marketing, 25(6), 410-419.

Jackson, G. \& Ahuja, V. (2016). Dawn of the digital age and the evolution of the marketing mix, Journal of Direct, Data and Digital Marketing Practice, 17, 170-186.

Jayaram, D., Manrai, A.K. \& Manrai, L.A. (2015). Effective use of marketing technology in Eastern Europe: Web analytics, social media, customer analytics, digital campaigns and mobile applications, Journal of Economics, Finance and Administrative Science, 20, 118-132.

\section{$\triangle$ Correspondence}

\section{Tešić Dejan}

Faculty of Economics Brčko

Studentska 11, 76100, Brčko, Bosnia and Herzegovina

E-mail: dejan.tesic.efb@gmail.com
Karjaluoto, H., Mustonen, N. \& Ulkuniemi, P. (2015). The role of digital channels in industrial marketing communications. Journal of Business and Industrial Marketing, 30(6), 703-710.

Kung, L. (2008). Strategic Management in the Media: theory to practice. London: Sage.

Levy, P. \& Birkner, C. (2011). Digital 45Marketing 2011: What you need to know. Marketing News, (3), 10-14.

Lewis, S. C. (2008). Where young adults intend to get news in five years. Newspaper Research Journal, 29(4), 3652.

Pew Research Center (2018). Internet Use Over Time: American Adults. Retrieved March 09, 2018 from http://www.pewinternet.org/data-trend/internetuse/internet-use-over-time/ .

Tešić, D. (2017). Shopper marketing as a function of modern distribution channels. Economic policy for smart, inclusive and sustainable growth, conference proceedings. Belgrade 307-329.

We are social (2018). Digital in 2018: World's internet users pass the 4 billion mark. Retrieved March 09, 2018 from https://wearesocial.com/uk/blog/2018/01/global-digitalreport-2018 .

Weber, L. (2009). Marketing to the Social Web: How Digital Customer Communities Build Your Business. Hoboken, NJ: Wiley.

Wymbs, C. (2011). Digital Marketing: The Time for a New "Academic Major" has Arrived. Journal of Marketing Education, 33(1), 93-106. 